\title{
FAITH AND POLITICS: THE RISE OF THE LASKAR JIHAD IN THE ERA OF TRANSITION IN INDONESIA ${ }^{1}$
}

\section{Noorhaidi Hasan}

\section{Introduction}

The turn of the twenty-first century witnessed the eruption of Islam into the political landscape of the Indonesian nation-state. Signs of this reassertion of political Islam might be seen in a variety of social movements that utilize Islam as a discursive center, ranging from the establishment of Islamic political parties to mounting demands for the implementation of the Islamic shari $a$, Muslim jurisprudence. More dramatically, the resurfacing of political Islam on the recent political scene of Indonesia, after the outbreak of a multidimensional socio-political and economic crisis, has been demonstrated by the emergence of a number of Muslim paramilitary groups, characterized by their distinctive appearance: wearing certain uniforms and carrying different kinds of weapons. Exploiting religious symbols, they behave as if they are military men and have conducted a variety of radical actions in the public sphere. This phenomenon undoubtedly spreads a sort of privatized militancy and violence.

Amongst a dozen such Muslim paramilitary groups, three major groups have recently come to the fore and made headlines by taking to the streets to demand the implementation of the Islamic shari $a$, conducting razzias at cafés, discotheques, and casinos, and, most importantly, sending thousands of militia troops to the Moluccan islands. These three major active groups are the Laskar Jihad (the Jihad Paramilitary Force), the Laskar Pembela Islam (the Paramilitary Force of the Defender of Islam),

I am grateful to a number of people who read the earlier drafts of this article and gave invaluable, critical comments, particularly Martin van Bruinessen, M. Khalid Masud, and Johan Hendrik Meuleman. 
and the Laskar Mujahidin Indonesia (the Indonesian Holy Warrior Paramilitary Force). They have complemented and facilitated the development of similar militant youth groups organized by a number of political parties, mass organizations, and the ruling regime. Among these groups are the Pemuda Pancasila (Pancasila Youth), the Barisan Pemuda Ka'bah (Ka'ba Youth Squad), the Satgas PDIP (Task Force of Indonesian Democratic Party-Struggle), the Banser Anshor (Anshor Assistance Unit for All Purposes), the Pamswakarsa (Self-Service Security Force), the Pendekar Banten (Banten Warriors), the Gerakan Pemuda Islam (Muslim Youth Movement), the Front Hizbullah (God's Army Front), and the Front Pemuda Islam (The Front of Muslim Youth).

The sudden proliferation of these Muslim paramilitary groups has certainly attracted the notice of many observers at home and abroad. Many of them speculate, without any attempt to give a critical assessment, that this proliferation is due simply to the attempts of some military and civilian personalities to mobilize certain groups in the society for their own political causes. Such speculation is certainly not sufficient to explain the complexity of this phenomenon, particularly since religion and politics are likely interwoven in it. It seems imperative, then, to present an analysis of these Muslim paramilitary groups in a broader framework, combining historical, theological, sociological, and political approaches.

This paper will focus primarily on the Laskar Jihad, the most ambitious and radical manifestation of political Islam in Indonesia today. In this paper, I shall explore the process of the creation of this particular Muslim paramilitary group and the backdrop of its emergence in the context of the major changes taking place in the socio-political and economic realms in Indonesia after the crackdown following the multidimensional crisis.

\section{The Laskar Jihad and Similar Groups}

The Laskar Jihad might be considered the most exclusive Muslim paramilitary group that emerged after the collapse of the New Order regime. It consists of around ten thousand young members, militants who prefer to wear jalabiyya, long flowing robes, and long beards. This group has also been the most active in sending voluntary militias to the Moluccan islands. It has emerged on the scene as an undoubtedly militant Islamic group, overwhelming much of the country through the onward march of its members willing to martyr themselves for the cause of God.

The Laskar Jihad is a paramilitary division of the Forum Komunikasi Ahlu Sunnah wal-Jama'ah (Communication Forum of the Followers of the Sunna and the Community of the Prophet), ${ }^{2}$ or, in short, FKAWJ, an organization which is, in fact, not supported

\footnotetext{
${ }^{2}$ The doctrine of this group is not to be confused with the doctrine ahl al-sunna wa al-jamāa $a$ developed by the Nahdhatul Ulama (NU), the biggest organization of traditionalist Muslims in Indonesia. Among NU members, the doctrine simply means Sunni Islam, which strictly follows one of the four orthodox schools of Islamic jurisprudence; see M. Ali Haidar, Nahdatul Ulama dan Islam di Indonesia: Pendekatan Fikih dalam Politik (Jakarta: Gramedia Pustaka Utama, 1998), p. 316; see also Martin van Bruinessen, NU: Tradisi, Relasi-relasi Kuasa, Pencarian Wacana Baru (Yogyakarta: LKIS, 1994), p. 21. The NU leader, Hasyim Muzadi, has questioned the use of this term by the Laskar Jihad members, and highlighted that the NU's doctrine ahl al-sunna wa al-jamā'a should not be confused with that of the Laskar Jihad.
} 
by mainstream Indonesian Islam. The FKAWJ was established by Ja'far Umar Thalib, and officially inaugurated at a tabligh akbar, a mass religious meeting, in Solo, Central Java, on February 14, 1998. Even before its official foundation, the FKAWJ was already in existence. It had its beginnings in the development of the Jama'ah Thya alSunnah (The Community of the Revival of the Sunna), which was basically an exclusive $d a^{`} w a$ (propagation of Islam) movement, insisting on the correct implementation of Islamic shari $a$. Even though we cannot deny some parallels with the major Islamist movements in the Muslim world during the twentieth century, particularly the Muslim Brotherhood and the Jama at-i Islami, the Ihya al-Sunnah community was more significantly influenced by Wahhabism, an official school of Saudi Arabia. Indeed, it was part of the so-called Salafi society, adopting the most puritanical Saudi style of Islam. This Salafi society began to proliferate in Indonesia in the beginning of the 1990s, particularly after the return of young graduates from Islamic universities in the Middle East. $^{3}$

Wahhabism was a major revivalist movement initiated by Muhammad ibn `Abd alWahhab (1703-1787), who drew inspiration from the teachings of Ahmad ibn Taymiyyah (1263-1328), a medieval scholar of Hanbalism, the strictest of the four legal schools of Sunni Islam. Assisted by a local prince, Muhammad ibn Sa'ud, this movement gained a considerable success in the Arabian Peninsula. With their puritanical spirit, the Wahhabis set out to fight against the superstitions prevalent in Arabian society and to attack those who claimed to be Muslim but whose behavior was, in their view, un-Islamic. They took a hard line in defining who could be regarded as a believer, stating that no deviation from the shari $a$ was permitted, and they drew a firm distinction between the world of believers and that of unbelievers. ${ }^{4}$ By drawing their inspiration more significantly from Wahhabism, the Salafi society distinguished itself from earlier Indonesian Muslim organizations by its strict adherence to an extreme puritanism, manifested in their appearance and in the enforcement of religious observance.

The Laskar Jihad began to catch the public eye when they held a tabligh akbar at the Senayan main stadium in Jakarta at the beginning of April 2000. Attended by about 100,000 participants, this tabligh akbar decried the "disaster" that had been afflicting the Moluccan Muslims, who were perceived to be confronted by a genocidal threat. Seeking to counteract the threat, Ja'far Umar Thalib, the leader of this group, proclaimed the necessity of raising the banner of $j i h \bar{a} d$, which, for this leader, means armed holy battle. ${ }^{5}$ Openly, he stated the determination of his members to go to the battlefield in the Moluccan islands and to stand with the Moluccan Muslims fighting against their Christian enemies. Subsequently, he established a paramilitary training camp in Bogor, a region near Jakarta, to train thousands of young men declaring themselves prepared to engage in combat in a number of troubled spots in Indonesia.

\footnotetext{
${ }^{3}$ Besides the Thya al-Sunnah, this society includes, to mention but a few, the Ihya al-Turath community, the Al-Sofwa, and the As-Sunna foundation, with branches and schools scattered all over Indonesia.

${ }^{4}$ John Obert Voll, Islam: Continuity and Change in the Modern World, 2nd edition (Syracuse: Syracuse University Press, 1994), pp. 53-56.

${ }^{5}$ In fact, the term jihäd has a spectrum of meanings, including struggle against one's own innermost selfish tendencies; for a detailed explication of this term, see, for instance, Bruce B. Lawrence, Defenders of God: The Fundamentalist Revolt against the Modern Age (Columbia: University of South Carolina, 1989), p. 217.
} 
After this tabligh akbar, the Laskar Jihad marched to the presidential palace. They demanded that the government restore social order and curb the ethno-religious conflict in the Moluccas. Six representatives of the Laskar Jihad met President Abdurrahman Wahid. They were Ja'far Umar Thalib, Ayif Syafruddin, Brigadier General (ret.) Rustam Kastor, Ali Fauzi, Abu Bakar Wahid al-Banjari, and Tasrif Tuasikal. They accused the president of favoring Christians in the Moluccas and of having led his country into the trap set by either a West-cum-Zionist conspiracy or, alternatively, a communist plot, as indicated by the escalation of the conflict occurring in the islands. The meeting came to an abrupt end after Wahid had them thrown out of his office. ${ }^{6}$

Following the first massive demonstration, the Laskar Jihad decided to do something concrete and sent their first mission, an investigation team, to the Moluccas. This team was charged with a special duty, namely to survey and carefully map the areas of conflict and the latest position of Muslims in the islands. Even though the political and military leaders in Jakarta forced them to cancel this mission, the members of the team eventually succeeded in landing in Ambon. At the port of the island, one member of this mission recounted, they were enthusiastically welcomed by some military men, who greeted them by saying, "Welcome to the jihäd battlefield," and they were immediately provided with a number of standard military weapons, including AK-47s and SS-14s. The success of this mission apparently convinced the Laskar Jihad that their struggle to rescue their Muslim brothers in the Moluccas should be continued. Fired by jihād fervor, waves of Laskar Jihad fighters have left for the Moluccan islands.

While the Laskar Jihad was very much concerned with what they called the jihäd action in the Moluccas, the Laskar Pembela Islam preferred to focus on sweeping actions against cafés, discotheques, casinos, and other venues they accused of being dens of iniquity. Despite their similarities, the latter group is different from the former, particularly in terms of their origins and institutional profiles. The Laskar Pembela Islam is, to a large extent, not founded on as firm an ideological and organizational basis as the Laskar Jihad. It is the paramilitary division of the Front Pembela Islam (the Front of the Defenders of Islam, FPI), which is often associated with a number of military and civilian personalities who are not ashamed to mobilize preman, gangsters, and other violence-prone groups in order to maintain their political interests. This group is led by Habib Rizieq Shihab (b. 1965), a young Arab from a family of sayyids, descendants of the Prophet. Habib Rizieq Shihab studied at King Muhammad ibn Saud University in Riyad under the sponsorship of the Organization of the Islamic Conference (OIC), a forum for political and economic cooperation between Muslim countries established in $1962 .^{\circ}$ A number of other leading figures among the sayyid families are also involved in the leadership of the Front Pembela Islam, including Habib

\footnotetext{
${ }^{6}$ This event was reported by various mass media. See, for instance, "Enam Wakil Laskar Jihad Bertemu Presiden," Kompas, April 7, 2000.

${ }^{7}$ Interview with a member of the team, Cempaka Putih Tengah, Jakarta, December 2000.

${ }^{8}$ See Hasan Moinuddin, Die Organisation der Islamischen Konferenz als Forum Politischer und Wirtschaftlicher Kooperation (Bochum: Brockmeyer, 1984), pp. 170-176.
} 
Husein al-Habsyi (b. 1955), the leader of the Indonesian Muslim Brotherhood, ${ }^{9}$ who served ten years of a twenty-year prison sentence for his activities associated with the bombing of the Borobudur stupa in 1985.

The Laskar Pembela Islam first made its presence felt in a massive demonstration on August 17, 1998, where it publicly challenged the different elements that had opposed B. J. Habibie as the president to succeed Suharto. This group emerged at a time when the Pamswakarsa, the Front Hizbullah, and the Gerakan Pemuda Islam began to be more vocal in their support for Habibie. These groups were initially formed by Suharto's supporters in response to the growing opposition to the former president. After their initial appearance, the Laskar Pembela Islam held earnest demonstrations to voice a variety of demands related to Islam, repeating the slogan al-amr bi al-ma'rüf wa al-nahy 'an al-munkar (enjoining good and forbidding evil). On one occasion, the members of the Laskar Pembela Islam attacked the Komisi Nasional Hak Azazi Manusia (National Commission of Human Rights, KOMNAS-HAM), condemning them for acting unfairly towards Muslims. At that time, the commission was occupied with an investigation concerning the past actions of certain army generals, particularly the then-minister of defense, Wiranto, who was suspected of having violated human rights during military operations in East Timor. ${ }^{10}$

Similarly, thousands of members of the Laskar Pembela Islam marched to the headquarters of the Majelis Permusyawaratan Rakyat (MPR, People's Consultative Assembly) during its session in August 2000, demanding that the MPR enforce the Jakarta Charter, once intended to be the preamble to the constitution. In this document, a statement "with the obligation to carry out the Islamic shar $\vec{a} a$ for its adherents" was added to the first principle (Belief in God) of the Pancasila, the ideology of the state, which would have given constitutional status to the shari $a$. It is worth noting that the debate on the Jakarta Charter can be traced back to the 1950s, when the Majelis Konstituante (Constituent Assembly) considered the proposal of Muslim parties to establish Islam as the foundation of the state in place of the Pancasila; the debate continued until the dissolution of the Majelis Konstituante in $1959 .{ }^{11}$ For the Laskar Pembela Islam, the implementation of the Jakarta Charter would lead to the revitalization of the supremacy of the shari $a$.

The revitalization of supremacy of the Islamic shari $a$ also constitutes the main theme voiced by the members of the Laskar Mujahidin Indonesia. This group is a loose alliance of a number of minor Muslim paramilitary groups and Muslim hard-line organizations scattered across various cities in Indonesia, where the Darul Islam rebellions had their roots. Included in the Laskar Mujahidin Indonesia are, to mention but a few organizations, the Laskar Santri (Muslim Student Paramilitary Force), the Laskar Jundullah (God's Army Paramilitary Force), the Kompi Badr (Badr Company), the Brigade Taliban (Taliban Brigade), and the Pasukan Komando Mujahidin (Mujahidin Command Force).

\footnotetext{
9 The establishment of this organization, allegedly an Indonesian branch of the originally Egyptian religious-political movement of this name, was made public on October 17, 1999, though it had existed as an underground political movement for several years.

${ }^{10}$ See "Habib di Panggung Politik," Gatra 08/VI (January 8, 2000).

${ }^{11}$ See B. J. Boland, The Struggle of Islam in Modern Indonesia (The Hague: Nijhoff, 1971).
} 
Organizationally, the Laskar Mujahidin Indonesia is under the umbrella of the Majelis Mujahidin Indonesia (Indonesian Holy Warrior Assembly), established as the result of the so-called "first national congress of mujähidin," which took place in Yogyakarta in 2000. This congress, indirectly supported by a number of Islamic organizations and political parties from the modernist end of the spectrum, discussed one central theme: the enforcement of the shar $\vec{i} a$ as absolutely necessary to curb the various problems and disasters afflicting contemporary Indonesia. Within the context of the implementation of the shari $\vec{a}$, the notions of khiläfa Islämiyya (Islamic caliphate), imāma (imamate), and jihād (holy war) were also discussed. ${ }^{12}$

The congress opened on August 5, 2000 and ended on August 7 with the establishment of the Majelis Mujahidin Indonesia by the participants. It seems to me that this date was not accidental. On the same date fifty-one years earlier, S. M. Kartosuwirjo proclaimed the Negara Islam Indonesia (Islamic State of Indonesia), pursuing an independent Islamic state within Indonesia. ${ }^{13}$ This so-called Darul Islam rebellion inspired the clandestine Negara Islam Indonesia (NII) movement, which first manifested itself in 1978 when a group using the name Usrah, literally meaning "family," was formed in Bandung. The movement spread into various cities; in the process, it was often identified by different names, such as the Jama'ah Islamiyah in Solo, the Generasi 554 in Jakarta, and the NII Cirebon in Cirebon. ${ }^{14}$

A number of leading personalities, including Deliar Noer, Mochtar Naim, Mawardi Noor, Ali Yafie, Alawi Muhammad, Ahmad Syahirul Alim, and A. M. Saefuddin, some of whom are also former members of Masyumi, were appointed as members of the socalled ahl al-hall wa al-aqd-literally "those who have the power to bind and unbind"- $a$ kind of supreme body in the organization which resembles an advisory council. ${ }^{15}$ This body is led by Abu Bakar Ba'ashir, the leader of the Ngruki Pesantren, a conservative Islamic boarding school in Solo, who was arrested in November 1978 for his responsibility for allegedly leading the Jama'ah Islamiyah. Giving a speech at "the first national congress of mujāhidin," he proclaimed that the application of Islamic shari $a$ was absolutely essential, and argued that its rejection must be countered by $j i h \bar{a} d .^{16}$ The congress itself was initiated by Irfan S. Awwas, now the chairman of the executive committee (lajna tanfidhiyya) of the assembly. He was the editor-in-chief of the banned magazine Arrisalah in Yogyakarta, and served nine years of a thirteen-year prison sentence for his activities associated with the Negara Islam Indonesia movement.

\footnotetext{
${ }^{12}$ Irfan S. Awwas, ed., Risalah Kongres Mujahidin I dan Penegakan Syari'ah Islam (Yogyakarta: Wihdah Press, 2001).

${ }^{13}$ See C. van Dijk, Rebellion under the Banner of Islam: the Darul Islam in Indonesia (The Hague: Nijhoff, 1981), p. 1.

${ }^{14}$ See June Chandra Santosa, Modernization, Utopia, and the Rise of Islamic Radicalism in Indonesia (PhD dissertation, Boston University, 1996), appendix 3.

${ }^{15}$ The concept of ahl al-hall wa al-agd is closely related to the concept shura (consultation), which is, in modern Islamist literature, usually interpreted as the basic element of democracy. The concept denies the legitimacy of authoritarian rule and makes the community the source of executive power. See, for instance, Ahmad S. Moussalli, Moderate and Radical Islamic Fundamentalism: The Quest for Modernity, Legitimacy, and the Islamic State (Gainesville: University Press of Florida, 1999), p. 121.

${ }^{16}$ Awwas, Risalah Kongres Mujahidin, p. 139.
} 
The emergence of these Muslim paramilitary civilian groups leads to some fundamental questions, particularly in relation to the process of how they came into existence. In order to deal with this issue, I will focus on the Laskar Jihad in my analysis. It is a good example of a group that has arisen as a consequence of interrelated developments at both the domestic and the international levels. In addition, this group best exemplifies the combination of different factors, both religious and political, in forging its activism and militancy.

\section{Biographical Sketch of the Leader of the Laskar Jihad}

The establishment and growth of the Laskar Jihad has been determined to a great extent by the role of their charismatic and millenarian leader, Ja'far Umar Thalib. A central figure among the Laskar Jihad voluntary fighters, he was active not only in setting up this Muslim paramilitary group, but also in defining its direction and activism. He was born into an Arab family in Malang, East Java, on December 29, 1961. His father was active in the al-Irshad movement, a reformist organization established in 1913 by Arabs living in the Netherlands East Indies, who were involved in a conflict with the sayyid community. Together with the Muhammadiyah and the Persatuan Islam (Islamic League), ${ }^{17}$ the al-Irshad, under the leadership of Ahmad Soorkatti (1872-1943), strove to purify Indonesian Muslims of the so-called tahayyul (superstitions), bid a (innovations), and khurafa (deviations) in their religious belief. ${ }^{18}$

Ja'far Umar Thalib completed his early education at his native town, Malang. After having finished secondary school at the Islamic Teacher Training School of Malang, he continued his studies at a pesantren of the Persatuan Islam in Bangil, East Java, in 1981. Disappointed with the pesantren, he went to Jakarta to continue his studies at the Institute for Islamic and Arabic Studies (LIPIA), an institute of higher learning sponsored by the Saudi Arabian government. While at the LIPIA, he was not only active in learning Arabic, but also became a leader of the student organization of the al-Irshad, which strongly opposed the Pancasila.

Ja'far Umar Thalib studied at the LIPIA for only three years, but in 1986 he had the opportunity to continue his study at the Maududi Islamic Institute in Pakistan. In the mid-1980s, many Indonesian students were given the opportunity to study in Saudi Arabia and Pakistan under the sponsorship of Dewan Dakwah Islamiyah Indonesia (Islamic Propagation Council of Indonesia, DDII). This project was considered crucial because it trained believers who were prepared to conduct $d a^{\prime} w a$ activities in opposition to Christian missionaries. The Dewan Dakwah Islamiyah Indonesia was established in 1967 by Muhammad Natsir (d. 1993), the former leader of Masyumi, who was obsessed with the idea that Islam was under siege primarily because of the expansion of Christian missionary projects. ${ }^{19}$ Through a personal relation of its leader,

\footnotetext{
${ }^{17}$ The Muhammadiyah was founded by Ahmad Dahlan (1869-1923) in Yogyakarta in 1912, while the Persatuan Islam, known as the Persis, was founded by Ahmad Hassan (1887-1958) in Bandung in 1920.

${ }^{18}$ Deliar Noer, The Modernist Muslim Movement in Indonesia: 1900-1942 (Singapore: Oxford University Press, 1973), pp. 63-85.

${ }^{19}$ See R. William Liddle, "Media Dakwah Scripturalism: One Form of Islamic Political Thought and Action in New Order Indonesia," in Towards a New Paradigm: Recent Developments in Indonesian Islamic Thought, ed. Mark R. Woodward (Arizona: Arizona State University Press, 1996), pp. 328-329.
} 
the Dewan Dakwah Islamiyah Indonesia has become associated with the Rabitat al'Alam al-Islami (Muslim World League), functioning as its representative in Indonesia since $1973 .^{20}$ The Rabita was one of the principal organizations used by Saudi Arabia in spreading Salafi-Wahhabi propaganda. ${ }^{21}$ The development of Salafi-Wahhabi propaganda, which urged followers to avoid issues of political power, began as an attempt by Saudi Arabia to protect its geo-strategic position, particularly against the challenges raised by secular Arab nationalism, which was being fueled by such leaders as Gamal Abdel Nasser of Egypt. This propaganda was extended and intensified in the 1980s after the outbreak of the Iranian revolution, which contested the legitimacy of the kingdom. ${ }^{22}$ Within this context, the Rabita has played a central part in distributing Saudi monies, which fund the proliferation of the Sunni Salafi-Wahhabi networks throughout the Muslim world and in Western countries as well. ${ }^{23}$

Before going back to his country of origin, in 1987 Ja'far Umar Thalib had the opportunity to visit Afghanistan, where mujāhidin were waging war against the Soviet Union. During the war, the Rabita, in cooperation with the Muslim Brotherhood and other Arab Islamist organizations, played a crucial role in sending young mujāhidīn volunteers from the Middle East to engage in combat side-by-side with Afghan fighters. The policy of the Rabita, the Muslim Brotherhood, and other Arab Islamist organizations was implemented by the Pakistani Jama'at-i Islami, ${ }^{24}$ their principal local counterpart, which created camps for military training, where the young mujāhidin volunteers trained before being sent to the front. ${ }^{25}$

There were a number of factions within the Afghan mujähidīn that were known to have received not only Saudi Arabian financial aid, but were also provided with voluntary fighters. ${ }^{26}$ They were, for instance, the Ittihad-i Islami Bara-i Azadi-yi Afghanistan, led by Abdul Rasul Sayyaf, the Jami at-i Islami, led by Burhanuddin Rabbani, and the Hizb-i Islami, led by Gulbudin Hekmatyar. Ja'far Umar Thalib initially joined one of these factions. Subsequently, however, he supported the Jama'at al-Da'wa ila al-Qur'an wa Ahl-i Hadith, ${ }^{27}$ a strict Salafi faction and Saudi "principality" led by Jamil al-Rahman, who applied the doctrine of takfir, requiring Muslims to excommunicate any sovereign considered apostate, and to resort to

\footnotetext{
${ }^{20}$ On the link between the Dewan Dakwah Islamiyah Indonesia and the Rabita, see Reinhard Schulze, Islamischer Internationalismus Im 20 Jahrhundert (Leiden: E. J. Brill, 1990), p. 260.

${ }^{21}$ See Barnett R. Rubin, "Arab Islamists in Afghanistan," in Political Islam: Revolution, Radicalism, or Reform?, ed. John L. Esposito (Colorado: Lynne Rienner Publishers, 1997), p. 185.

${ }^{22}$ See Oliver Roy, The Failure of Political Islam, trans. Carol Volk (Harvard: Harvard University Press, 1996), pp. 112-117; see also Shireen T. Hunter, The Future of Islam and the West: Clash of Civilizations or Peaceful Coexistence? (Westport: The Center for Strategic and International Studies, 1998), pp. 155 ff.

${ }^{23}$ An example is the Revival of Islamic Da' wa society, which is headquartered in Toronto, Canada. See the homepage of this group at http://www.troid.org. This society was mentioned by the spokesman of the FKAWJ, when I asked him about the kitabs (guidebooks) and ulamas (guidelines) commonly referred to by the FKAWJ members.

${ }^{24}$ On this political organization, see Seyyed Vali Reza Nasr, The Vanguard of the Islamic Revolution (London: I. B. Tauris, 1994).

${ }^{25}$ Rubin, "Arab Islamists in Afghanistan," pp. 184-186.

${ }^{26}$ On the flow of Saudi arms and money to Afghanistan, see also Ahmed Rashid, Taliban, Islam, Oil and the New Great Game in Central Asia (London: I. B. Tauris, 2000), p. 85.

${ }^{27}$ See "Profil Ja'far Umar Thalib: Pelopor Jihad ke Ambon," Forum Keadilan, No. 7 (May 20, 2001), p. 37.
} 
violence, should it be necessary. ${ }^{28}$ This faction had special relations with the Pakistani Ahl-i Hadith, a reformist movement founded in the Indian sub-continent in the nineteenth century. This movement was inspired by the teachings of Shah Wali Allah al-Dihlawi (1702-1762). Over the course of history, this movement transformed itself into a political party, enjoying direct support from Saudi Arabia (in collaboration with the United States) in its attempts to support Afghan mujähidin. For the same reason, a Salafi Ahl-i Hadith-based militant armed Islamic group, Da`wa al-Irshad or Lashkar Tayyiba, was even established in 1987 in Pakistan. This group inculcated the spirit of jih $\bar{a} d$ and provided military training for potential mujähidin ${ }^{29}$

In 1989, Ja'far Umar Thalib landed in Jakarta. Back in Indonesia, he was immediately involved in teaching activities in a pesantren of the al-Irshad in Salatiga, Central Java. In 1991, he went to Yemen in order to widen his insight into Wahhabiya teachings with a Yemeni teacher, Muqbil ibn Hadi al-Wadi i, known for his links with the conservative Islamist Islah party and the Saudi-funded Salafi-Wahhabi movement in Yemen today ${ }^{30}$ During the hajj months, he repeatedly went to Mecca and Medina to perform the hajj. While performing the hajj, Ja'far Umar Thalib sought out and attended religious lectures held by a number of prominent Saudi Salafi-Wahhabi teachers, including Muhammad Nasr al-Din al-Albani (d. 1999) and 'Abd al-'Aziz 'Abd Allah bin Baz (1912-1999). Born in Albania, Nasr al-Din al-Albani had lived and studied for a long time in Damascus before moving to Saudi Arabia, where he became a wellknown scholar of the prophetic tradition. He wrote some works on the validity of hadìths, including Silsila al-Ahädith al-Sahìha (The valid genealogy of the hadiths). Expertise in hadith linked Nasr al-Din al-Albani to 'Abd Allah bin Baz, who was known as the official grand mufti of Saudi Arabia. 'Abd Allah bin Baz had enjoyed a remarkable career as a university teacher and a judge before he became a grand mufti. His fatwās are collected in his greatest book, Majmū 'al-Fatāwā (The compilation of fatwäs). Some other Saudi Salafi-Wahhabi teachers were also visited by Ja'far Umar Thalib, particularly Rabi' ibn Hadi 'Umar al-Madkhali, a hadith lecturer at the Islamic University of Medina, who has written a number of works, including Manhaj al-Anbiya fi al-Dà wa ila Allāh (The method of the prophets in calling towards Allah). This book contains guidelines for the practice of the Wahhabi $d a{ }^{2} w a^{31}$

Ja'far Umar Thalib returned to Indonesia in 1993, choosing to live in Yogyakarta. In this city, he began to make his voice heard by giving religious lectures and sermons at the Muslim students' discussion groups, known as the kelompok pengajian or halaqah (literally, study circles), around university campuses in Yogyakarta. As a figure who

\footnotetext{
${ }^{28}$ Roy, The Failure of Political Islam, p. 36.

${ }^{29}$ For further information about the Lashkar Tayyiba, see Saeed Shafqat, "Religious Groups: Rise of Dawat-ul-Irshad/Lashkar-e-Tayyaba and the Problem of Democratic Framework in Pakistan," unpublished paper presented in the seminar organized by Pakistan Study Groups, Paris on December 13, 1999.

${ }^{30}$ Look through http: / / www.al-bab.com, for different subjects and articles. His name is also written as Sheikh Muqbil al-Wada'i. As for the connection between Yemeni Salafi and al-Islah, see Eric Watkins, "Islamism and Tribalism in Yemen," in Islamic Fundamentalism, ed. Abdel Salam Sidahmed and Anoushiravan Ehtshami (Colorado \& Oxford: Westview Press, 1996), pp. 215-225; see also Paul Dresch and Bernard Haykel, "Stereotypes and Political Styles: Islamists and Tribesfolk in Yemen," The International Journal of Middle East Studies 27 (1995): 405-431.

${ }^{31}$ Various interviews with the Laskar Jihad members, Yogyakarta and Jakarta, September-November 2000.
} 
had mastered a wide range of religious knowledge, Ja'far Umar Thalib quickly attracted numerous followers among the participants. In 1994, he decided to establish a pesantren and community called "Jama'ah Ihya al-Sunnah" at Kaliurang, Yogyakarta.

\section{The Manhaj Salafi: Doctrine and Ideology of the Ihya al-Sunnah}

As implied by its name, the Ihya al-Sunnah placed emphasis on the revitalization of Islam in all aspects of life through the practice of returning to the model of the Salaf al-Sälih, the pious Muslims of the first generation. The backdrop of this call was its claim that Muslims, induced by a variety of temptations offered by the contemporary secular, Western world, have neglected true Islam as taught by the Salaf al-Sälih. This abandonment, according to the Ihya al-Sunnah, has brought about the collapse of the glory of Islam. The Thya al-Sunnah community was convinced that only by a return to the doctrine of the Salaf al-Sālih would Muslims be able to steer away from deviations in their practice of the faith, and this would lead Muslims to regain their lost triumphs. ${ }^{32}$ Referred to by the Ihya al-Sunnah as either "Manhaj Salafi" (The system of the pious ancestors) or "Manhaj Ahl al-Hadith" (The system of the followers of the Prophet's traditions), this doctrine undoubtedly represents the search for authenticity, which implies puritanical ideals, better known in Islam as Salafism.

As I have indicated before, unlike earlier Muslim modernist organizations in Indonesia, which were more significantly influenced by Muhammad Abduh (18491905) and Muhammad Rashid Rida (1865-1935), two premier Muslim reformists, the Thya al-Sunnah was squarely within the puritanical Salafi-Wahhabi tradition. This can be seen, for instance, in the fact that among the members of the Thya al-Sunnah community, the canonical books written by Muhammad ibn 'Abd al-Wahhab, Ahmad Ibn Taymiyyah, and Muhammad Abu Bakr ibn Qayyim, the disciple of Ibn Taymiyyah, were widely read as guidelines to understanding and defining Islam. In their books, the Qur'an and the Sunna are given particular emphasis as the basis for the Wahhabi definition of true Islam.

True to their advocacy of the espousal of the return to the doctrine of the Salaf alSālih according to the Saudi Wahhabi model, the Ihya al-Sunnah community avoided discussing politics, or, more precisely, engaging questions of political power. Instead, they concentrated on re-Islamizing society at a grassroots level by insisting on the correct implementation of the shar $\vec{i} a$ by individuals, particularly through preaching and the establishment of Islamized spaces. Within this context, the Thya al-Sunnah members persistently encouraged people to go to mosques to perform prayers collectively five times a day and persuaded them to join the Thya al-Sunnah community. In addition to that, the Ihya al-Sunnah members have attempted to develop an exclusive pattern of performance, clothing, and social relations, which they claimed were modeled on patterns followed by Salaf al-Sālih. They have preferred, for instance, to adopt traditional clothing-a long white shirt, baggy trousers gathered

\footnotetext{
${ }^{32}$ See editorial notes of the first edition of the journal Salafy, published by the Ihya al-Sunnah (Salafy 1, 1995), p. 1.
} 
above the ankle, and headgear-and allowed their beards to grow long. ${ }^{33}$ They also rejected all distractions: music, theater, and places of pleasure and entertainment, such as cafés, discotheques, and dance clubs. ${ }^{34}$ Perfume, the cinema, television, and photographs were even considered anathema to Muslims. ${ }^{35}$ Female members wore long black dresses and covered their faces with veils. They were secluded from the men and were only allowed to have contact with males in the presence of their husbands or of mahrims, the close relatives whom they are not allowed to marry. In short, their social interactions were highly restricted. ${ }^{36}$

The Thya al-Sunnah believed that if every Muslim consistently followed the doctrine of the Salaf al-Sālih in his or her daily life, society would automatically become Islamic. This, in turn, would change the face of the state.$^{37}$ When that happened, for the Thya alSunnah, there would no longer be any need to establish an Islamic state. Given its attitude, it was not surprising that the Ihya al-Sunnah did not see eye-to-eye with movements that sought to turn Indonesia into an official Islamic state, such as the Negara Islam Indonesia. Ja'far Umar Thalib also criticized the doctrine of the Muslim Brotherhood, which advocated the revival of the Islamic caliphate, khiläfa Islämiyya. Ja'far Umar Thalib believed that such a goal would concentrate all Muslim minds and energies on political interests, and he contended that this principle had already caused bloody conflicts among Muslims. ${ }^{38}$

As far as the Ihya al-Sunnah community is concerned, the implementation of the shar $\vec{i} a$ by individuals, as described above, was thus much more important than the establishment of an Islamic state. Such a tendency is called by Olivier Roy "neofundamentalism," a movement that began to spread across the political landscape of the Muslim world in the mid-1980s. Its proliferation was caused partly by the failure of revolutionary Islamism, a modern Islamic political movement which claims to re-create a true Muslim society, not merely by the application of the shar $\vec{i} a$, but also by creating a new Islamic order through revolutionary and militant political actions. ${ }^{39}$

\section{The Halaqahs: Site of Recruitment of the Ihya al-Sunnah Cadres}

The prime recruits targeted by the Ihya al-Sunnah $d a{ }^{\prime} w a$ movement were initially participants in the halaqahs, which have spread widely since the 1980 s throughout

\footnotetext{
${ }^{33}$ Cutting the beard is considered wicked, since such an act brings Muslims into invidious comparison with infidels. See Abu Nu'aim M. Faisal Jamil al-Madani, "Jenggot dalam Pandangan Islam," Salafy 7 (1996): 3537.

${ }^{34}$ Music and movies, for instance, were considered heretical entertainments that should be avoided; see "Jebakan-jebakan Iblis," Salafy 24 (1998): 24.

${ }^{35}$ On their rejection of these things, see the fatwās of the Ahlu Sunnah published in Salafy.

${ }^{36}$ See, for instance, Abu Zaki Fathur Rahman, "Hukum Berjabat Tangan dengan Wanita Bukan Mahram" and "Hukum Keluarnya Seorang Wanita Memakai Minyak Wangi," Salafy 4 (1996): 6-7. These articles compile some fatwās of the grand muftì of Saudi Arabia, 'Abd al-'Aziz ibn Baz, on the issues of women shaking hands with men and using perfume. Neither is allowed.

37 See Ja'far Umar Thalib, "Dakwah Salafiyah di Persimpangan Jalan," Salafy 1 (1995): 39-42.

${ }^{38}$ See Ja'far Umar Thalib, "Fitnah Sururiyah Memecah Belah Umat," Salafy 2 (1996): 17.

${ }^{39}$ Roy, The Failure of Political Islam, p. 25.
} 
many campuses of "secular" universities in Indonesia, including Gadjah Mada, National Veteran, Diponegoro, Airlangga, Bandung Institute of Technology, Bogor Institute of Agriculture, and the University of Indonesia. These halaqahs were groups which insisted on the need for a moral revolution in order to confront the increasingly secularized, decadent world. ${ }^{40}$

The growth of the halagahs can be studied against the background of the beginning of the 1970s, when Imaduddin Abdurrahim, who received personal support from Muhammad Natsir, introduced the program called Latihan Mujahid Dakwah (Da'wa Activist Training) at the Salman Mosque of the Bandung Institute of Technology. Abdurrahim was a former secretary of the Islamic International Federation of Student Organizations (IIFSO), a Rabita-linked student organization. ${ }^{41}$ Specifically, this training program was aimed at training new cadres among university students prepared to conduct $d a^{\prime} w a$ activities in the broader society.

There can be little doubt that the spirit and euphoria inspired by the success of the Iranian revolution in 1979 contributed a great deal to the expansion of the halagahs at university campuses throughout Indonesia. This revolution provided not only inspiration, but also a blueprint for Muslims all over the world to struggle for the creation of Islamic states. In the years that followed, the Muslim world witnessed what John Esposito calls an "Islamic resurgence," marked by an increasing interest among Muslims in implementing religious teachings into various aspects of life. ${ }^{42}$

This current of Islamic resurgence coincided, at the national level, with a restrictive policy prohibiting university students from playing an active part in politics. This policy, known as the Normalization of Campus Policy (NKK, BKK), to a large extent closed public spheres at university campuses and limited the dynamics of student organizations. It was later strengthened by government enforcement of the Pancasila as the sole foundation (asas-tunggal) of all political and mass organizations. In these distressing and discouraging circumstances, the religious locus was one of the few remaining open spaces attractive to students.

The halagahs were particularly appealing to students who came from either small towns or rural areas, or the urban lower-middle classes. Benefiting from the government program of mass education, which broadened the chances of the younger generation to receive a university education, they were able to continue their studies at different prestigious universities in the cities of Indonesia. In the cities, however, they were vulnerable to culture shock, as they were immediately granted access to the world of pleasure, luxury and consumption, but suffered conflict when they could not detach themselves from their rural roots. This problem was exacerbated by their anxiety about the future and job prospects. The government's program to recruit more university students led to student overpopulation, which inevitably created fierce competition for

\footnotetext{
${ }^{40}$ See M. M. Billah, "Gerakan Kelompok Islam di Yogyakarta," in Gerakan Islam Kontemporer di Indonesia, ed. Abdul Aziz, Imam Tholkhah, Soetarman (Jakarta: Pustaka Firdaus, 1989), pp. 293-295.

${ }^{41}$ On the role played by Imaduddin Abdurrahim in the proliferation of halaqahs and his proximity to Natsir, see Asna Husin, Philosophical and Sociological Aspects of Da'wah: A Study of Dewan Dakwah Islamiyah Indonesia (PhD dissertation, Columbia University, 1988), p. 168.

${ }^{42}$ John L. Esposito, Voices of Resurgent Islam (New York: Oxford University Press, 1983), p. 17.
} 
jobs, since the number of university graduates entering the job market increased significantly.

In such an atmosphere, Ja'far Umar Thalib offered participants in the halagahs what might be called an appropriate channel and new zeal, for he promised them the opportunity to create alternative communities that would provide them with more security in facing the future. As a result, many of these students, particularly from the universities in Yogyakarta and Central Java, soon became part of the Thya al-Sunnah community. ${ }^{43}$ Interestingly, most of the students who joined the Thya al-Sunnah community came from the scientific and technical disciplines, particularly from schools of medicine, forestry, engineering, mathematics, and the natural sciences. The students in these disciplines were trained in the framework of mathematic formulas. They were very enthusiastic about Ja'far Umar Thalib's ideas, which they took literally. In addition, many students from such backgrounds experienced a kind of spiritual void and a "guilty feeling," given their fascination with the progress of the West in terms of science and technology. A desire to compensate for this fascination, which they saw as mistaken, impelled them to join the Ihya al-Sunnah and other similar groups. ${ }^{44}$ After graduating from the universities, many of those who had been involved in the Thya alSunnah community enthusiastically maintained their engagement with Ja'far Umar Thalib and his brand of activism.

\section{The FKAWJ: Organization and Membership}

As I shall elaborate below, the major changes taking place in the socio-political and economic realms of Indonesia after the eruption of the multidimensional crisis in 1998 likely stimulated the transformation of the Ihya al-Sunnah into the FKAWJ. This change also meant a shift in orientation: from the non-political $d a{ }^{\prime} w a$ into political activism. ${ }^{45}$ When Ja'far Umar Thalib established the FKAWJ, the Ihya al-Sunnah membership immediately provided enthusiastic support. They served as the backbone of the organization, formulating and organizing various programs and actions of the FKAWJ. It was also from among them that Ja'far Umar Thalib recruited his best soldiers to fill the available positions in the FKAWJ organization.

Different from the Thya al-Sunnah, which was an informal organization based on a shared interpretation of Islam, the FKAWJ is a formal, centralized organization, which enables Ja'far Umar Thalib to mobilize his followers for collective action. William Gamson's seminal study of collective action concludes that such highly centralized bureaucratic organizations are the most effective mechanisms for realizing success in

\footnotetext{
43 "Target Kami Menyingkirkan Gus Dur," Interview with Ja'far Umar Thalib, Panji Masyarakat 01, IV (April 26, 2000).

${ }^{44}$ I am grateful to M. Khalid Masud, who introduced me to this term and shared his perspective with me.

${ }^{45}$ This shift into political activism caused conflict and fragmentation in Salafi society in Indonesia. Abu Nida, who played an important role in initiating the Salafi da' wa in Yogyakarta, prepared to oppose Ja'far Umar Thalib's FKAWJ. Similarly, Abu Faiz Asifuddin and Yazid Jawwas strongly criticized Ja'far Umar Thalib's political actions. Abu Nida has been occupied with his own group, Jama'ah Ihya al-Turath, while Abu Faiz and Jazid Jawwas established Jama'ah al-Sunnah and al-Sofwah, respectively.
} 
social movements because of the readily available sources of labor, efficient decisionmaking structures, and a high degree of combat readiness. ${ }^{46}$

The FKAWJ has a relatively modern organizational structure. It has a central executive board, whose headquarters are located in Yogyakarta. This executive board is led by Ayib Safruddin, a young graduate of the psychology faculty at Muhammadiyah University of Surakarta. He is assisted by a secretary, Ma'ruf Bahun, an engineer from Haluoleo University in Central Sulawesi. The executive board has a number of divisions, each of which is headed by a divisional leader. The majority of the divisional leaders are university graduates. ${ }^{47}$ This central executive board supervises provincial and district branches. Provincial branches have been established in twenty-four provinces of Indonesia. Each provincial branch has a number of district branches.

In the organization's hierarchy, an advisory body has authority over the central executive board; this advisory body is actually a supreme religious board led by Ja'far Umar Thalib. This advisory body is comprised of fifty-four young religious intellectuals, the majority of whom have been trained by Salafi-Wahhabi teachers or have studied at different universities in the Middle East, including King Muhammad Ibn Saud and Medina Islamic Universities. Each member of this board is responsible for giving religious lectures in different branches of the FKAWJ. Together with the university graduates who become the organizers of the FKAWJ, they constitute the movement's leaders, and are responsible for mobilizing all FKAWJ collective actions.

Most of the rank-and-file members of FKAWJ are low-income people, university students, and the unemployed. Most are young people from rural areas where FKAWJ branches have been established. Every branch of the FKAWJ organizes regular religious lectures, through which the Salafi-Wahhabi teachings are disseminated among the participants from the surrounding areas. In addition to this, the FKAWJ maintains twelve pesantrens throughout Indonesia. The chief task of these pesantrens is to educate orphans and neglected children who are old enough to go to school. In these pesantrens, such conventional subjects as Arabic, Islamic theology, Islamic jurisprudence, the theories of the Qur'an, and the hadith are taught. From these pesantrens, the student element in the FKAWJ masses is generally recruited. The total number of all FKAWJ members is estimated at approximately forty thousand people. ${ }^{48}$

In order to recruit new members and collect money from sympathizers, the Laskar Jihad has also set up "stands" near mosques, schools, traffic lights, and other public venues. Without hesitation or reluctance, they frequently address passers-by to tell them about the ferocity of Christian enemies. They also distribute the bulletin Maluku Hari Ini (The Moluccas Today), containing the Laskar Jihad version of the Moluccan

\footnotetext{
${ }^{46}$ William A Gamson, The Strategy of Social Protest (Homewood: Dorsey Press, 1975).

${ }^{47}$ On the persons appointed as members of the executive board, see http://www.fkawj.org. In mid-2001, there were some small changes in the organizational structure of the FKAWJ and its personnel; see the same home page.

${ }^{48}$ Interview with Hardiyanto, Kaliurang, Yogyakarta, November 3, 2000; I am grateful to Muhammad Wildan, who helped me in conducting this interview.
} 
conflict in daily reports. They have insisted that they are ready to do anything to defend Islam, including sacrificing their own lives. ${ }^{49}$

Although there are a number of rumors associating the FKAWJ with military and civilian political personalities, the FKAWJ itself claims to be an independent organization. In an interview with the fortnightly Panji Masyarakat, the modernist Muslim Indonesian magazine, Ja'far Umar Thalib totally rejected all speculation about the involvement of either Wiranto (the former military chief and minister of defense), Fuad Bawazier (the former minister of finance, associated with the al-Irshad and known as having ties to the Suharto family), or any other political figures associated with Habibie in FKAWJ activities. ${ }^{50}$ In my interview, nevertheless, the representatives of the FKAWJ did not deny having received some financial and other support both from Indonesia and abroad, particularly Malaysia, Japan, and the Middle East. ${ }^{51}$

The FKAWJ's organizational symbol-two crossed swords with the words "La ilāha illa Allah, Muhammad Rasul Allah" (There is no God but Allah and Muhammad is His messenger) printed on them-gives a clear indication of the militancy with which they are prepared to defend their beliefs. This militancy manifested itself on January 30,2000 , with the establishment of the Laskar Jihad, a special military division within the FKAWJ. As soon as it was established, a command structure resembling that of the army was created: the Laskar Jihad consists of brigades, battalions, companies, platoons, and teams, and it even has its own intelligence service. Ja'far Umar Thalib himself was appointed commander-in-chief of the Laskar Jihad. He is assisted by a number of field commanders, including Ali Fauzi and Abu Bakar Wahid al-Banjari.

The Laskar Jihad itself has approximately ten thousand members. Of that number, by September 2000, there were around three thousand members who had been engaged in combat in the Moluccas. ${ }^{52}$ The number of the Laskar Jihad fighters involved in the Moluccan conflict has remained fairly constant, with new fighters coming to the islands to replace those returning home.

\section{The Multidimensional Crisis: Turning Point of the Thya al-Sunnah}

As I have indicated, the transformation of the Thya al-Sunnah into the FKAWJ occurred when a significant change took place in the political landscape of Indonesia, following the multidimensional crisis afflicting the country. This crisis not only acted as the catalyst that ultimately forced Suharto to resign from the presidency; it also stimulated the forging of free political space. The so-called Reformation Era has arrived, but, ironically, the living conditions of the people have steadily worsened. Many have lost their jobs, and with them their future security. These problems have

\footnotetext{
${ }^{49}$ By December 2000, around twenty fighters of the Laskar Jihad had died in the Moluccas.

${ }^{50}$ See "Target Kami," Panji Masyarakat 1, IV (April 26, 2000).

${ }^{51}$ Interview with Hardiyanto, Campaka Putih Tengah, Jakarta, December 9, 2000.

${ }^{52}$ Interview with Ayib Safruddin, Sabili 7,VIII (September 20, 2000).
} 
produced numerous demonstrations that have occasionally exploded into violence and riots. $^{53}$

When Habibie was appointed Suharto's successor, he was faced not only with this multidimensional crisis, but also, and immediately, with strong opposition from different elements in society, particularly those supporting Megawati Sukarnoputri, who protested against Habibie persistently, demanding his resignation. At one point in time, Megawati's supporters threatened that, if Habibie were not prepared to step down at the extraordinary session of the MPR in November 1999, "People Power," a united front composed of leftist students and the Barisan Nasional (National Front), as well as other pro-Megawati groups, would force him out of office.

In reacting to this pressure, Habibie's supporters, mobilized by various Islamic organizations from the modernist end of the spectrum-including the Partai Persatuan Pembangunan (People United Party), the Dewan Dakwah Islamiyah Indonesia, the Badan Kerjasama Pondok Pesantren Seluruh Indonesia (the Islamic Boarding School Cooperative Council of Indonesia), the Komite Indonesia untuk Solidaritas Dunia Islam (Indonesian Committee for Islamic World Solidarity), and the Centre for Information and Development Studies-came out in force to stand behind Habibie. ${ }^{54}$ These organizations were supported by a number of influential figures, such as Hamzah Haz, Anwar Harjono, Hartono Mardjono, M. Kholil Ridwan, Ahmad Sumargono, Eggy Sudjana, Fadli Zon, and Adi Sasono, some of whom were well-known allies of Lieutenant General (ret.) Prabowo Subianto. ${ }^{55}$ Prabowo (son-in-law of Suharto) was dismissed from the army during Habibie's presidency for his alleged role in kidnapping some activists, and also for his role in the violent riots of March 13-14, 1998, which he is suspected of having triggered in an attempt to discredit popular opposition to Suharto and, at the same time, to force Wiranto, his strongest rival, into a corner. ${ }^{56}$

Following the pressure and protests against Habibie, rumors that a Christian-cumZionist plot or an evil communist alliance was working to undermine and seriously harm the most populous Muslim country in the world suddenly became more prevalent, inevitably shocking many people. ${ }^{57}$ Such rumors were believed to be produced by Ahmad Sumargono, Eggy Sujana, and Fadli Zon, all known for their prominence among regimist Muslims, in their efforts to seek an issue that might unite and mobilize Muslims against opposing forces. ${ }^{58}$

As the pressure against Habibie mounted, the Ihya al-Sunnah community became a participant in the political discourse of the state. Its official publication, the monthly magazine Salafy, lost no time in publishing the Thya al-Sunnah standpoint concerning

\footnotetext{
${ }^{53}$ On the violence and riots following the crisis, see Cees van Dijk, A Country in Despair: Indonesia between 1997 and 2000 (Leiden: KITLV Press, 2001), pp. 111-113.

${ }^{54}$ Adam Schwarz, A Nation in Waiting: Indonesia's Search for Stability, 2nd edition (Colorado: Westview Press, 2000) pp. 349 and 368-369; see also van Dijk, A Country in Despair, pp. 332-333.

${ }^{55}$ On the proximity of Prabowo and these figures, see "Mengapa Prabowo Mendekat," Sabili 4, VI (September 2, 1998): 10-11.

${ }^{56}$ See Robert W. Hefner, Civil Islam: Muslims and Democratization in Indonesia (Princeton: Princeton University Press, 2000), p. 206.

${ }^{57}$ On these rumors, see Schwarz, A Nation in Waiting, pp. 347-348.

${ }^{58}$ Hefner, Civil Islam, p. 207
} 
recent developments in the political realm. They condemned the practice of Western democracy and identified Zionist-cum-Christian and/or communist conspirators as the parties allegedly responsible for the spread of democratic and communist ideas in the country. In one of his articles, Ja'far Umar Thalib referred to democracy as an unIslamic, troublesome institution visiting disaster upon Indonesia today. He is convinced that sovereignty does not belong to people; it belongs absolutely to Allah. Allah is the only sovereign who should be obeyed. There is no law except the law of God. ${ }^{59}$

The Apel Siaga (Call for Readiness) held by the FKAWJ in Solo in February 1999 obviously reflected the growing anxiety of the FKAWJ about the political developments of the time. At this Apel Siaga, the FKAWJ warned Muslims not to fall into the trap set by their enemies. According to them, the best way to guard against such an eventuality was to support consistently an Islamic government led by a pious Muslim. The meeting also declared that Muslims were required to wage war against a government led by an infidel (seorang yang kafir), ${ }^{60}$ a declaration that called to mind the doctrine of takfir of Sayyid Qutb. ${ }^{61}$

As the general election of June 1999 approached, the rivalry between Habibie and Megawati gained momentum. In efforts to attack the other party, various issues exploiting ethnic, religious, and other primordial sentiments were raised by supporters of each party. One remarkable example was the case of Theo Syafei, a Roman Catholic who was an influential supporter of Megawati. He made a speech, a tape of which was widely circulated, about a plan by members of the political elite to transform Indonesia into an Islamic republic by the year 2010. Commenting on this proposal, he stated that Christian, rather than Islamic, notions had inspired and been the basis for Indonesia's penal code and human rights ideals, so that the role of Christians in the historical course of the Indonesian nation-state should not be neglected. This speech inspired harsh protests from a variety of Muslim organizations and individuals, particularly from the Komite Indonesia untuk Solidaritas Dunia Islam (Indonesian Committee for Islamic World Solidarity, KISDI) and the Ikatan Cendekiawan Muslim se-Indonesia (Indonesian Association of Muslim Intellectuals, ICMI), and many of these groups used it as a weapon against Megawati. ${ }^{62}$

In the thick of this rivalry, a merciless debate emerged over whether or not a woman could be president. As the leader of the Indonesian Democratic Party-Struggle (PDI-P), Megawati was a strong potential candidate to challenge Habibie, who was closely associated with Islam. For Megawati's supporters, the time had indeed come to stand behind her to win the election at all costs. Some pro-Megawati groups in Surabaya, for instance, stated their determination to die for Megawati, demonstrated by a petition signed in blood. In their counter-arguments, Habibie's supporters insisted that

\footnotetext{
${ }^{39}$ Ja'far Umar Thalib, "Menyoal Demokrasi," Salafy 30 (1999): 4-5; see also "Suara Rakyat Tunduk pada Suara Tuhan," Suara Hidayatullah (July 1999): 1-6.

${ }^{61}$ On the analysis of this doctrine and Sayyid Qutb's thoughts in general, see Ahmad S. Moussalli, Radical Islamic Fundamentalism: The Ideological and Political Discourse of Sayyid Qutb (Beirut: American University of Beirut, 1992).

${ }^{62}$ See van Dijk, A Country in Despair, pp 380-381.
} 
defending Habibie necessarily meant defending Islam, and the Islamization of the state. Consequently, the campaigns of both sides resorted to aggressive tactics, even violence.

As part of the campaign to disqualify Megawati as a candidate, pictures of Megawati praying at a Balinese Hindu temple had appeared in Indonesian newspapers. Megawati's detractors immediately seized upon this image to suggest that she was a Hindu. A. M. Saefuddin, a Partai Persatuan Pembangunan (PPP, Unity Development Party) minister in Habibie's cabinet, went even further, asking: are we ready to be led by a Hindu president? Infuriated by Saefuddin's insinuation, Balinese Hindus held a demonstration demanding that Habibie discharge Saefuddin from his cabinet.

Concerned about Megawati's candidacy, the Thya al-Sunnah community asked Ibrahim ibn Amir al-Ruhaili, a Saudi Salafi mufti who was a lecturer at the Islamic University of Medina, about how they should react if she were elected. On the basis of the questions, a fat $w \bar{a}$ (religious decree) was issued. This fatwō declared that:

To appoint a woman to be the leader of a Muslim state is disavowed [munkar]. We are not allowed to choose a Muslim woman to be the leader of Muslim men, just as we are not allowed to appoint a sinful man to be the leader. But if the woman has already been elected to be president, but then signs of her sinfulness emerge, we would not be allowed to resist against her. In principle, a woman cannot be appointed to be a leader. To appoint a woman as president is an act which contradicts the guidance of the Prophet. ${ }^{63}$

\section{Islamization Policy and the Resurfacing of Political Islam}

The linkage between Habibie and his Muslim supporters can be traced back to the Islamization strategy established by Suharto's New Order in the last decade of its rule. Beginning in the 1990s, Suharto introduced an Islamization strategy, particularly focusing on the accentuation of Islamic symbols in public discourse and the accommodation of religious socio-political powers. In the context of this strategy, a number of organizations and institutions that made use of Islamic symbols have come to the fore. The Islamic Court Bill was introduced, followed by the presidential decree on the Compilation of Islamic Law. Islamic shari $a$ banks and insurance companies sprang up everywhere, and thousands of mosques were built under the sponsorship of the state. Most importantly, the ICMI was established under Suharto's patronage, and Habibie, as a close associate of Suharto, was appointed the leader of the organization. ${ }^{64}$ At the same time, there was also a growth in popularity of the jilbab, an Islamic head covering for women, the hajj, pilgrimage to Mecca, and religious rituals and festivals. ${ }^{65}$ In the wake of the introduction of this conservative Islamization strategy, within a very short time, the state drastically moved away from its former secular position, and prominent Muslim figures emerged as actors in national politics.

\footnotetext{
63 "Sikap Umat Islam Bila Megawati Jadi Presiden," Salafy 33 (1999): 53-54.

${ }^{64}$ Martin van Bruinessen, "Islamic State or State Islam? Fifty Years of State-Islam Relations in Indonesia," in Indonesien Am Ende Des 20. Jahrhunderts: Analyses zu 50 Jahren Unabhaengiger Entwickling, Deutsche in Indonesien, ed. Ingrid Wessel (Hamburg: Abera, 1996), pp. 48-49.

${ }^{65}$ Ibid., p. 47.
} 
This Islamization strategy was believed by a number of scholars to be a way to contain the spread of the legitimacy crisis experienced by the New Order after more than twenty years of power. ${ }^{66}$ This crisis occurred partly because the state, while failing to fulfill the requirements of social welfare, was unwilling to provide sufficient space for all segments of society to express themselves and pursue their interests. In spite of the considerable role played by Muslims in founding and supporting the New Order, the expression of political Islam, for instance, had been marginalized throughout Suharto's tenure and even repressed by the authoritarian state.

Indeed, the marginalization of political Islam was responsible for a number of protests. Different Islamist uprisings labeled ekstrem kanan (extreme right), which demanded, for example, the application of the Jakarta Charter, had broken out since the end of the 1960s. Such protests were often followed by the damaging of Christian churches and the destruction of night clubs and gambling casinos. ${ }^{67}$ Islamist rebellion movements also emerged, like the Komando Jihad (Jihad Command), which advocated the establishment of an Islamic state. These movements were consistently and violently crushed by the state. ${ }^{68}$ In the face of the New Order repression, all attempts to protest and rebel were bound to end with failure, inevitably creating a feeling of deprivation and frustration among their constituency. This frustration reached its peak when the state successfully forced all socio-political organizations to accept the Pancasila as their sole foundation. Many were forced either to disguise their real "faces" or to move their activities underground.

The state-run Islamization project was supported by many Islamist groups, who, having lost hope, affiliated themselves with the project, or at least felt that they were going in that direction. Indeed, many groups saw this as a promising opportunity. Muslims who had been forced to remain on the periphery, or who had been given limited space in national politics, found a new way to enter the political, social, and economic arenas of the state. They believed that they would be able to change the fate of their society, their nation, and their state-not to mention bringing about changes at the personal level. In this sense, the strategy of the regime appeared to succeed in "subduing" a variety of Muslim opposition groups. Suddenly there emerged what Robert Hefner calls "regimist Islam," which did not recoil from showing itself to be a real partner of the state. ${ }^{69}$ When Suharto's New Order was being severely challenged, not long before its collapse, the regimist Islamists strove to show their loyalty to the president and attempted to help him maintain his position by, among other tactics, spreading anti-Chinese rumors and the Zionist-cum-Christian conspiracy theory.

Nevertheless, the fall of Suharto was inevitable. By the time he left office, the optimism of the regimist Islamists that the Islamized direction of the state would be maintained was fading. Their only hope was that Habibie would be able to sustain this

\footnotetext{
${ }^{66}$ See, e.g., Douglas Ramage, Politics in Indonesia: Democracy, Islam, and Ideology of Tolerance (London: Routledge, 1995).

${ }^{67}$ See Harold Crouch, "Indonesia," in The Politics of Islamic Reassertion, ed. Mohammed Ayoob (London: Croom Helm, 1981), p. 203.

${ }^{68}$ On these rebellions and the indications of the involvement of some intelligence agents in the rebellions, see van Bruinessen, "Islamic State or State Islam?," pp. 43-46.

${ }^{69}$ See Hefner, Civil Islam, pp. 128-143.
} 
strategy. However, the embattled Habibie could not do so. Pressured by various elements in Indonesian society, he accommodated the demand for a new general election in June 1999 and facilitated that election.

In this general election, the constituency of regimist Islam, scattered throughout such different parties as the Partai Persatuan Pembangunan (PPP, the Unity and Development Party), the Partai Bulan Bintang (PBB, the Crescent and Star Party), and the Golongan Karya (Golkar, Party of Functional Groups), demonstrated their support for Habibie. Nevertheless, this scarcely mounted a serious challenge to Megawati Sukarnoputri with her PDI-P; 35.7 million votes went to her party, making it the winner of the 1999 general election. However, partly because of the political maneuvers of the Poros Tengah (Middle Axis), a political alliance of Muslim parties led by Amin Rais, the election failed to give Megawati the presidency. Instead, it brought Abdurrahman Wahid to power.

Abdurrahman Wahid's accession to power was welcomed with euphoria by many, including Muslims. He was considered a leader who would be able to diminish the tensions between the supporters of Habibie and Megawati. Nevertheless, as a public figure who had often produced controversial statements and policies, Abdurrahman Wahid soon had to confront opposition from different elements in Indonesian society. During his efforts to restructure the military leadership, waves of protests against him mounted considerably and led to an opposition movement in parliament.

While protest and opposition escalated, the economic and social conditions in the nation worsened. The value of the rupiah dropped again. Manufacturers stopped producing and exporting products. International trust plummeted. The ethno-religious conflict in the Moluccas spun increasingly out of control and cost hundreds of lives. Observing these recent developments, Ja'far Umar Thalib argued that these problems were very much related to the performance of the government, the breakdown of sociocultural boundaries, the systematic condemnation of the Indonesian military, and the increase in security disturbances. ${ }^{70}$ As a consequence, the FKAWJ felt that there were sufficient grounds to demand Abdurrahman Wahid's resignation.

In addition, for the FKAWJ, Abdurrahman Wahid was believed to be indifferent to the fate of Muslims. From their perspective, Abdurrahman Wahid had failed to show strong support for Muslims and so had effectively collaborated with Israeli-Zionist and Christian powers and thus facilitated a communist resurgence. They cited the welcoming of an Israeli trade delegation, the proposal to revive the Partai Komunis Indonesia, the widespread availability of leftist and communist-leaning books, and, most importantly, the increasing ethno-religious conflicts in the Moluccas and other areas in Indonesia as examples of Abdurrahman Wahid's intimacy with "the three main powers which are hostile to Muslims." On these grounds, Ja'far Umar Thalib came to the conclusion that Abdurrahman Wahid was al-sultān al-jā'ir (an unjust ruler), who should no longer be obeyed. ${ }^{71}$

\footnotetext{
${ }^{70}$ Ja'far Umar Thalib, "Saatnya Mengobarkan Jihad," Salafy 34 (2000): 2.

71 "Target Kami," Panji Masyarakat 1,VI (April 26, 2000).
} 


\section{Jihād in the Moluccas}

As we have noted, in conjunction with the increasing ethno-religious conflicts in the Moluccan islands and other areas in the Indonesian archipelago, rumors about an evil conspiracy between the enemies of the Muslims working to undermine the power of Islam became more prevalent. The conflict in the Moluccas, in particular, was believed to be part of a Zionist-cum-Christian project, led by the Republik Maluku Selatan (the South Moluccan Republic, RMS), a separatist movement with headquarters located in the Netherlands.

According to the Laskar Jihad, the Zionist-cum-Christian international powers are working to damage the glory of Islam in Indonesia by fomenting the disintegration of the country and "Christianizing" Indonesian Muslims. The Moluccan islands are simply a "pilot project" in this larger effort, the success of which will determine their subsequent agenda. Laskar Jihad insists that jihād is the only solution to counter the evil efforts of the Zionist-cum-Christian conspiracy. ${ }^{72}$

The Moluccan conflict broke out at the beginning of 1999. Since its eruption, it has provided primarily stories of the defeat of Muslims on almost all fronts. A number of newspapers and magazines, such as the Sabili fortnightly magazine, with a circulation reaching more than seventy thousand, have covered such stories vigorously. Certainly, the anxiety and furious anger of many Indonesian Muslims were aroused, which resulted in an explosion of rallies and demonstrations demanding the government curb the violence.

In reacting to the deteriorating situation, Salafy published some fatwās about what the FKAWJ referred to as "the Moluccan war." There have been seven fatwās, issued by seven different $m u f t \bar{s}$, concerning the hukm (legal position) of being engaged in the war in the islands. These fatwās were issued following the first massive demonstration of the Laskar Jihad, and emphasized the seriousness of the contacts the Laskar Jihad had made with their authoritative Saudi Salafi muftis before launching their actions.

In the opinion of 'Abd al-Muhsin al-'Abbad, a Medina Salafi mufti, traveling to the battlefield in the Moluccas to defend the Muslims in the islands is lawful (disyariatkan), provided that it is not harmful to Muslims themselves, and that Muslims are in a defensive position. Ahmad al-Najm, a member of the Saudi senior 'ulama committee, agreed with the necessity of waging jih $\bar{a} d$ in Ambon and suggested that Muslims were obligated to help their oppressed brothers. But this mufti warned the Laskar Jihad fighters first to take the following steps: (1) to choose a representative who would meet the ruler, to advise and approach him; (2) if the ruler took their suggestions into consideration, he should be obeyed; (3) if the ruler rejected their suggestions, Muslims were allowed to rebel against him, as long as they had sufficient power.

More obviously, the engagement of Muslims in the Moluccan war was judged by Muqbil ibn Hadi al-Wadi i, a Salafi mufti in Yemen, to be an individual duty (fard 'ain) for Indonesian Muslims and to be a collective duty (fard kifäya) for Muslims outside Indonesia. Taking the same tone, Rabi' ibn Hadi al-Madkhali, a Salafi mufti in Saudi

\footnotetext{
${ }^{72}$ Ja'far Umar Thalib, "Jihad fi Sabil Allah: Solusi Problematika Bangsa dan Negara Indonesia," Salafy 34 (2000): 33 .
} 
Arabia, argued that the engagement of Muslims in the Moluccan war was a fard ain, since Muslims were being attacked by Christians.

The necessity of helping the Moluccan Muslims who were being attacked by their Christian enemies was also declared by Salih al-Suhaimi, a Salafi muftī in Medina. He stated that jihād is compulsory in troubled areas, providing Muslims have sufficient power to undertake it. The same point was argued by Wahid al-Jabiri, a Salafi mufti in Medina. He was of the opinion that to defend Muslims being attacked by their enemies is compulsory.

Finally, in his fatw $\bar{a}$, Muhammad ibn Hadi al-Madkhali, a Salafi mufti in Medina, confirmed the lawfulness of the three steps that the Laskar Jihad had taken before going to Ambon. He said these steps, including the tabligh akbar, the meeting with Abdurrahman Wahid, and the military training in Bogor, were lawful, and sufficient to legitimize jihäd actions in the Moluccas. Abdurrahman Wahid's prohibition of jih $\bar{a} d$ in Ambon was judged unlawful, and consequently there was no longer any need to obey him. Quoting a hadith of the Prophet, he said, "It is not allowed to obey someone in committing disobedience of Allah." ${ }^{73}$

On the basis of these fatwās, Ja'far Umar Thalib declared the Moluccan war a holy war against Christian enemies attacking Muslims. He emphasized that engagement in the war was a duty that should be fulfilled by Muslims in order to honor Allah's message. ${ }^{74}$ Quoting Ibn Taymiyyah, Ja'far Umar Thalib said, "Should our enemy attack Muslims, to confront the attack would be an obligation incumbent on the Muslims who are being attacked and it would be compulsory for other Muslims to help them." ${ }^{75}$ According to Ja'far Umar Thalib, this was obligatory, because since it had succumbed to the pressure from Zionist-cum-Christian international powers, the government did not have the ability or the power to end the war. ${ }^{76}$

After these fatwās had been distributed, the stories about martyrs that were meticulously recounted in a specific column in the Salafy magazine apparently began to resonate among Laskar Jihad loyalists. "The war in the Moluccas has provides a golden opportunity to become a martyr, who can look forward to being welcomed in heaven by angels," said one candidate of the Laskar Jihad volunteers. The Laskar Jihad fighters believe it is the time to conduct al-jihäd al-akbar, the true Islamic jiha $\bar{d} .^{7}$

Authorized by the fatwās, the "holy war" in the Moluccas has apparently become integrated into the international jiha $\bar{d}$ movement, which demands the participation of the umma, Muslim community. The Laskar Jihad indeed portrays itself as being the defender and guardian of the umma, whose lives are in jeopardy, so long as the state does not have sufficient power and political will to protect them. In such a situation,

\footnotetext{
${ }^{73}$ See "Fatwa Para Ulama tentang Jihad di Maluku," http://www.laskariihad.or.id/risalah/fatwa; see also Ja'far Umar Thalib, "Menepis Rekayasa Fatwa Seputar Jihad di Maluku," Salafy 34 (2000): 6-9.

${ }^{74}$ For a detailed discussion of the way the radical Islamists understand the term "jihöd," see J. J. G. Jansen, Neglected Duty: The Creed of Sadat's Assassins and Islamic Resurgence in the Middle East (London: Macmillan, 1986), pp. 15-31.

75 "Fatwa Para Ulama tentang Jihad di Maluku," p. 7.

${ }^{76}$ Ibid., p. 10.

"Interview with members of the FKAWJ, Cempaka Putih Tengah, Jakarta, December 2000.
} 
jiha $\bar{d}$ is believed to be the only way to rescue the umma, as practiced by the Prophet Muhammad when Muslims were defending themselves from the käfir harb (attacking infidels). "Muslims should wake up and wage jihãd against the harb enemies threatening Muslim lives," stated one Laskar Jihad veteran, who had just returned from the Moluccas. ${ }^{78}$

The spirit and motivation for both defending the religion of Allah and reviving the glory of Islam are persistently pumped into the Laskar Jihad fighters. Motivated to obtain a reward from Allah, thousands of the Laskar Jihad fighters have left for the Moluccas; they claim to have travaled at their own expense. They insisted that they were not reluctant to sell their property, like motorcycles or domestic cows taken from their parents, to finance their travel to the islands. Upon their return from the jihadd, those who survived narrate their heroic stories to audiences of prospective mujähidin and to reporters for various publications of the Laskar Jihad. Several dozen of them have been martyred in the islands.

The portrayal of this conflict as a war between Muslims and Christians entails the projection of the medieval Christian crusades into the present. The Laskar Jihad fighters indeed frequently associate the Moluccan war with a Proyek Kristenisasi Salib (Christianization Crusade Project). Such an association provides a valid reason to reject the incorporation of the World of Islam into the globalization process.

It is not surprising that, in this war, the integration between jihād and $d a{ }^{`} w a$ has been emphasized. Jihād is portrayed as a form of Islamic propagation intended to build an ideal society, an alternative society free from Western cultural stains. It is part of propagation activities aimed at "giving a correct understanding of prescriptions

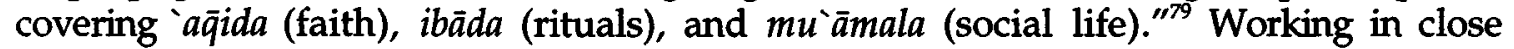
cooperation with local Muslims, Laskar Jihad fighters have also established dozens of health clinics, refugee camps, schools, and mosques. By integrating jihād with da'wa, the attempt to resist globalization has found a firmer basis, since the waging of war is only considered part of da'wa. Reordering society according to their own ideal model-which contrasts with the existing globalized world order-seems to be much more important to them.

\section{Epilogue}

As the demands for the implementation of the shari a have become more fluently articulated across the country, Laskar Jihad fighters have attempted to prove that they are indeed ready to espouse shari $a$. At the end of March 2001, the Laskar Jihad enforced a rajm sentence against one of its members, who committed rape in Ambon. He was stoned to death after being interrogated by a Laskar Jihad Sharīa Court led by Ja'far Umar Thalib. He admitted his crime and accepted his punishment without protest. Before the sentence was handed down to him, Ja'far Umar Thalib reminded all the people present in the court, "What we do will be regarded by Allah as sincerity in

\footnotetext{
${ }^{78}$ Interview with Laskar Jihad fighters, Cempaka Putih Tengah, Jakarta, December 2000.

${ }^{79}$ See http://www.laskarjihad.or.id.
} 
168 Noorhaidi Hasan

upholding the religion of Allah, because of which Allah will endow us with victory in our jihād. ${ }^{\prime 80}$

A month after the execution of this sentence, Ja'far Umar Thalib was arrested by the police. He was accused of the torture to death of one of his followers and of incitement to criminal violence. In reaction to this arrest, a number of Islamic organizations like the Komite Indonesia untuk Solidaritas Dunia Islam, the Dewan Dakwah Islamiyah Indonesia, the Badan Kerjasama Pondok Pesantren Seluruh Indonesia, and the Perguruan Islam al-Syafi'iyyah (Al-Syafi'iyyah Islamic Institution of Learning), held a mass religious meeting in front of the Dewan Dakwah Islamiyah Indonesia office in Jakarta to demand the release of Ja'far Umar Thalib. The meeting was also attended by the leaders of these organizations, including Hartono Mardjono, Hussein Umar, Kholil Ridwan, and Daud Rasyid, who stated their determination to defend Ja'far Umar Thalib. ${ }^{81}$ In conjunction with the demand for Ja'far Umar Thalib's release, the so-called Gerakan Anti Komunis (Anti-Communist Movement) conducted sweeps for leftist and communist-leaning books and burned them publicly. A few weeks later, Ja'far Umar Thalib was released by the police.

In July 2001, during an extraordinary session of the MPR, Megawati Sukarnoputri was installed as president, replacing Abdurrahman Wahid, and Hamzah Haz was elected as vice-president. The Laskar Jihad promptly reacted by organizing a tabligh akbar in Yogyakarta. Once again, they proclaimed their determination to continue jiha $\bar{d}$ actions and send militia troops to troubled regions, particularly Poso, Central Sulawesi. $^{82}$ A few days later, a delegation of the Laskar Jihad visited Hamzah Haz's office to voice their rejection of a woman president, claiming that her appointment was a great sin committed by Indonesian Muslims. In addition, they stated the necessity of implementing the shari $a$, as if they were demanding the fulfillment of a promise given by this PPP party leader. Reacting to this demand, Hamzah Haz asked them to behave in a manner that would display Islam as rahmatan li al-ialamin (a blessing for the whole universe), and not to appeal continually to militancy and violence. ${ }^{83}$

Following the attacks on Afghanistan by the US and its allies-a response to the terrorist attacks on the World Trade Center in New York in September 2001-a number of Indonesian Muslim hard-line groups held demonstrations in front of the US Embassy in Jakarta. ${ }^{84}$ They condemned the attack on Afghanistan and demanded that the Indonesian government sever diplomatic ties with the US. Interestingly, the Laskar Jihad did not involve themselves in the demonstrations. This absence was confirmed by a representative of the Laskar Jihad, who pointed out that demonstrations constitute a form of democratic expression totally forbidden by Salafi teaching. For the Laskar

\footnotetext{
80 "Laskar Jihad Tegakkan Hukum Allah: Rajam Anggotanya Yang Melakukan Zina," http:/www.laskarjihad.or.id/berita/March 2001.

81 “Beberapa Pengacara Siap Bela Panglima Laskar Jihad," May 5, 2001, http:/ / www.berpolitik.com.

82 "Ribuan Laskar Jihad Siap ke Poso," August 7, 2001, http://www.laskarjihad.or.id/berita.

${ }^{83}$ See "Laskar Jihad Berharap Pemerintah Serius Tangani Kasus Kerusuhan," Kompas, August 8, 2001; see also "Panglima Laskar Jihad Bertemu Wakil Presiden," http://www.laskarjihad.or.id/berita, August 9 , 2001.

${ }^{84}$ For detailed information on the anti-America demonstrations, see http:/ / www.detik.com (accessed October 18, 2001).
} 
Jihad, any person who participated in those demonstrations committed a $\sin ^{85}$ Nevertheless, in a television interview the day before, Ja'far Umar Thalib stated that ten thousand fighters were prepared to wage jih̄o $d$ in Afghanistan. This threat seemed more real when he visited many FKAWJ branches to warn troops to be in readiness for such an action. ${ }^{86} \mathrm{Ja}^{\prime}$ far Umar Thalib even sent the following sarcastic message to the US: "We would like to sorrow over the United States, you should learn from your own arrogance. For Muslims, we would like to congratulate you for the revenge upon terrors committed by the biggest terrorist nation in the world, the United States, on Muslim nations. ${ }^{187}$

It seems to me that jihäd has become a common word, characterizing a variety of discourses in Indonesia. This word is usually combined with the language of otherness and anti-Westernism and communism, identified by Bruce $B$. Lawrence as the hallmarks of Islamic fundamentalism. ${ }^{88}$ Even though there are some signs of the proliferation of Islamic fundamentalism in Indonesia, nobody knows to what extent it will influence the future course of the country. One thing is clear: the violence, to quote Roy, "is more a sign of weakness than the harbinger of a new wave of Islamic militancy. ${ }^{189}$ Political Islam remains on the political periphery, and may never succeed in changing the strategic landscape of the Muslim world. It is worth noting that the militant Islamic groups we have discussed are essentially not supported by mainstream Indonesian Muslims. Generally, I am in accord with Azyumardi Azra, who asserts that "once Indonesia attains a new equilibrium in this painful transition, most-if not all—of these Muslim hard-line groups will lose momentum." ${ }^{\prime 90}$

\footnotetext{
${ }^{85}$ Interview with Hardi Ibnu Harun, Cempaka Putih Tengah, October 20, 2001.

86 "Bersiaga Melawan Amerika," Bulletin Laskar Jihad Ahlus Sunnah wal Jama'ah 10 (October 2001): 8-9.

${ }^{87}$ Ja'far Umar Thalib, "Mampuslah Amerika," Bulletin Laskar Jihad Ahlus Sunnah wal Jama'ah, 10 (October 2001): 9.

${ }^{88}$ Lawrence, Defenders of God (Columbia: University of South Carolina, 1989).

${ }^{89}$ Olivier Roy, "Changing Patterns among Radical Islamic Movements," Brown Journal of World Affairs VI,1 (Winter/Spring 1999): 119.

${ }^{90}$ Azyumardi Azra, "Globalization of Indonesian Muslim Discourse: Contemporary Religio-Intellectual Connections Between Indonesia and the Middle East," in Islam in the Era of Globalization: Muslim Attitudes towards Modernity and Identity, ed. Johan Meuleman (Jakarta: INIS, 2001), p. 50.
} 
